\title{
METODE TAFSIR KONTEMPORER
}

\author{
Syufa'at
}

\section{Abstract}

Contemporary discussion among Moslem scholars about the way to understand, interpret, and apply al Quran in daily life is based on a belief that al Qur'an as the last bible of God's revelation can be adjusted at anytime and anywhere. In accordance to understand God's revelation objectively, moslems have to concern about the language and socio-cultural setting factors.

Kata Kunci: Hadis dan Pendapat Sababat, Takwil, Setting Sosial

\section{A. Pendahuluan}

Al-Qur'an adalah kitab suci untuk manusia. Ia menyebut dirinya sebagai petunjuk bagi manusia (budan li al-nās) dan penjelasanpenjelasan mengenai petunjuk itu dan pembeda antara yang haq dan batil (Q.S. al-Baqarah: 185). Ia juga berfungsi memberi petunjuk ke jalan yang sebaik-baiknya (Q.S. al-Isra': 9). Al-Qur'an memberikan petunjuk dalam persoalan-persoalan akidah, syari'ah, dan akhlak dengan jalan meletakkan prinsip-prinsip dasar tersebut. Allah menugaskan kepada Nabi-Nya untuk memberikan keterangan-keterangan yang lengkap mengenai dasar-dasar itu. "Kami telah menurunkan kepadamu al-dziker (Al-Qur'an) untuk kamu terangkan kepada manusia apa-apa yang diturunkan kepada mereka agar mereka berfikir (Q.S. al-Nahl: 44). Di samping keterangan yang disampaikan oleh Rasulullah SAW,

'Penulis adalah dosen tetap Jurusan Syariah STAIN Purwokerto, sedang menempuh Program Doktor di IAIN Walisongo Semarang. 
Allah memerintahkan pula kepada umat manusia seluruhnya agar memperhatikan dan mempelajari al-Qur'ān (Q.S. Muhammad: 24).

Dengan demikian, maka mempelajari al-Qur'an adalah kewajiban begitu pula halnya mempelajari hadis-hadis Nabi SAW yang menjelaskannya, agar ia benar-benar berfungsi sebagai petunjuk dalam berbagai bidang kehidupan manusia.

Redaksi ayat-ayat al-Qur'ān, tidak dapat dijangkau maksudnya secara pasti kecuali oleh pemilik redaksi tersebut. Hal ini kemudian menimbulkan keanekaragaman penafsiran. Dalam hal al-Qur'ān, para sahabat Nabi sekalipun yang secara umum menyaksikan turunnya wahyu, mengetahui konteksnya, serta memahami secara alamiah struktur bahasa dan arti kosakatanya, tidak jarang berbeda pendapat, atau bahkan keliru dalam pemahaman tentang maksud firman-firman Allah tersebut. ${ }^{1}$ Dari sini kemudian para ulama menggarisbawahi bahwa tafsir adalah "penjelasan tentang arti atau maksud firman-firman Allah sesuai dengan kemampuan manusia (mufassir), ${ }^{2}$ dan kepastian arti satu kosakata atau ayat tidak mungkin atau hampir tidak mungkin dicapai kalau pandangan hanya tertuju kepada kosakata atau ayat tersebut secara berdiri sendiri. ${ }^{3}$ Untuk memahami kandungan makna dan nilai yang ada dalam al-Qur'an dibutuhkan perangkat metodologi yang memadai dan sistematis dengan merujuk kepada ilmu-ilmu pokok dalam tafsir dan ilmu-ilmu bantu yang mendukungnya.

\section{B. Penafsiran Teks Keagamaan}

Penafsiran teks keagamaan selalu mempertautkan antara dimensi normativitas wahyu dan historisitas pemahaman wahyu. Yang pertama adalah wilayah kembali kepada al-Qur'ān dan Sunnah, sedangkan yang kedua adalah wilayah ijtihad dan tajdid.Normativitas wahyu akan tetap

'M. Quraish Shihab, Membumikan Al-Qur'an, (Bandung: Mizan, 1992), hal. 75.

${ }^{2}$ Muhammad Husain al-Dzahabi, al-Tafsir wa al-Mufassirūn (Mesir: Dār al-Kutub alHadisah, 1961), I: 15.

${ }^{3}$ M. Quraish Shihab, Membumikan, hal. 75. 
seperti apa adanya, seperti yang termaktub dalam sumber ajaran (teks keagamaan) yaitu al-Qur'ān dan Hadis. Tetapi historisitas pemaknaan dan pemahamannya berubah-ubah, kaya alternatif sesuai dengan tantangan zaman yang terus berubah.

Dari segi syarat penafsir secara umum dan pokok dapat disimpulkan sebagai berikut :

1. Pengetahuan tentang Bahasa Arab dalam berbagai bidangnya.

2. Pengetahuan tentang ilmu-ilmu al-Qur'ān, sejarah turunnya, hadis Nabi, dan usul fikih.

3. Pengetahuan tentang prinsip-prinsip pokok keagamaan.

4. Pengetahuan tentang disiplin ilmu yang menjadi materi bahasan. ${ }^{4}$

\section{Pembaharuan Tafsir}

Terdapat beberapa pokok pandangan yang dapat dijadikan pegangan dalam pembaharuan dalam bidang tafsir:

\section{Hadis dan Pendapat Sahabat}

Seorang mufassir tidak dapat mengabaikan hadis-hadis Rasulullah SAW dan pendapat sahabat. Penafsiran yang paling ideal adalah tafsir bi al-ma'thür, yakni yang berlandaskan ayat, hadis dan pendapat sahabat dalam menafsirkan al-Qur'ān. Hanya saja ini bukan berarti bahwa penafsiran mereka tidak dapat dikembangkan maknanya. Penafsiran Nabi saw dan sahabat dapat dibagi dalam dua kategori, yaitu: (a) là majâla li al-'aql fỉ (masalah yang diungkapkan bukan dalam wilayah nalar), seperti masalah-masalah metafisika dan perincian ibadah. (b) fimajal al-'aql (dalam wilayah nalar), seperti masalah-masalah kemasyarakatan. ${ }^{5}$

Pertama, apabila nilai riwayatnya șahīh, diterima sebagaimana adanya tanpa pengembangan, karena sifatnya yang berada di luar

${ }^{4}$ Ibid., hal. 79.

${ }^{5} \mathrm{M}$ Quraish Shihab, "Tafsir dan Modernisasi” dalam Ulumul Qur'an, No. 8, vol. II, 1991, hal. 36. 
jangkauan akal. Adapun yang kedua, walaupun harus diakui bahwa penafsiran Nabi SAW adalah benar adanya, namun penafsiran itu harus didudukkan pada proporsinya yang tepat. Ini karena sifat penafsirannya sangat bervariasi, baik dari segi motif penafsiran, baik berbentuk ta'nf, atau $i r s h \bar{a}$, atau tașhị dan sebagainya maupun hubungan antara ayat yang ditafsirkan dengan penafsiran yang juga beragam, seperti hubungan padanan (tațābuq), hubungan kelaziman (tatazsm), hubungan cakupan (tad'armmum), dan hubungan percontohan (tamthil). ${ }^{6}$

Di samping keragaman penafsiran seperti yang dikemukakan di atas, hadis-hadis Nabi pun dapat ditinjau dari berbagai segi, sejalan dengan kedudukan Nabi SAW ketika mengucapkan atau memperagakannya. Imām al-Qarāfî dianggap sebagai orang pertama yang memilah-milah ucapan dan sikap Nabi SAW. Menurutnya, Nabi terkadang berperan sebagai imam, qadi (penetap hukum), atau mufti yang amat dalam pengetahuannya. Pendapat di atas bagi penganut paham kontekstual dijabarkan dan dikembangkan lebih jauh, sehingga setiap hadis harus dicari konteksnya, apakah ia diucapkan atau diperankan oleh Nabi dalam kedudukan sebagai :

a. Rasul dan karena itu pasti benar, sebab bersumber dari Allah SWT.

b. Mufti yang memberi fatwa berdasarkan pemahaman dan wewenang yang diberikan Allah, dan inipun pasti benar serta berlaku umum bagi setiap muslim.

c. Hakim yang memutuskan perkara. Dalam hal ini putusan tersebut walaupun secara formal pasti benar, namun secara material adakalanya keliru. Hal ini diakibatkan oleh kemampuan salah satu pihak yang bersengketa dalam menutup-nutupi kebenaran, sementara di sisi lain keputusan ini hanya berlaku bagi pihak-pihak yang bersengketa.

d. Pemimpin suatu masyarakat yang menyesuaikan sikap, bimbingan, dan petunjuknya sesuai dengan kondisi dan budaya masyarakat yang temui. Dalam hal ini, sikap dan bimbingan tersebut pasti benar 
dan sesuai dengan masyarakatnya. Namun bagi masyarakat yang lain mereka dapat mempelajari nilai-nilai yang terkandung dalam petunjuk dan bimbingan itu untuk diterapkan sesuai dengan kondisi masing-masing masyarakat.

e. Pribadi baik karena (1) memiliki kekhususan dan hak-hak tertentu yang dianugerahkan atau dibebankan oleh Allah dalam rangka tugas kenabiannya, seperti kewajiban șalat malam atau kebolehan menghimpun lebih dari empat orang istri dalam satu waktu yang bersamaan; maupun karena (2) kekhususan-kekhususan yang diakibatkan oleh sifat manusia, yang berbeda antara seorang dengan orang yang lain, seperti perasaan suka, atau tidak suka terhadap sesuatu. ${ }^{7}$

Adapun pendapat-pendapat sahabat, maka apabila permasalahan yang dikemukakan termasuk fimā là majalab li al'-aql fib maka ia $f i b u k i$ al-marfú' (bersumber dari Nabi), sehingga ia diterima sebagaimana adanya. Sedangkan bila sifatnya tidak demikian, maka ia hanya dipertimbangkan, dipilah, dan dipilih mana yang sesuai dan mana yang tidak. $^{8}$

\section{Penggunaan Takwil dan Metafora}

Pada masa al-salaf al-awerwal, para ulama enggan menggunakan takwil atau memberi arti metaforis bagi teks-teks keagamaan. Imām Malik misalnya enggan membenarkan seseorang berkata "langit menurunkan hujan". Harus diyakini bahwa sesungguhnya yang menurunkannya adalah Allah SWT. Keengganan menggunakan takwil ini menjadikan sementara ulama salaf menduga bahwa batu adalah makhluk hidup yang berakal, berdasarkan firman Allah dalam Q.S. 2: 74. Juga ada yang menduga bahwa Allah mengutus nabi-nabi kepada

'M Quraish Shihab, 'Kata Pengantar' pada Shaikh Muhamad al-Ghazāi, Studi Kritis Atas Hadis, (Bandung: Mizan, 1994), hal. 9-10.

${ }^{8}$ Idem, Tafsir, hal. 36. 
lebah berdasarkan Q.S. $16: 68$. Setelah masa al-salaf al-arerval, keadaan telah berubah. Hampir seluruh ulama telah mengakui perlunya takwil dalam berbagai bentuknya. al-Suyūți, misalnya menilai mā̄a sebagai salah satu bentuk keindahan bahasa.Namun, walaupun mereka telah sepakat menerimanya, perbedaan pendapat timbul dalam menetapkan syarat-syarat bagi penggunaannya. ${ }^{9}$

Al-Shatibi mengemukakan dua syarat pokok bagi penakwilan ayat-ayat al-Qur'an. Pertama, makna yang dipilih sesuai dengan hakikat kebenaran yang diakui oleh mereka yang memiliki otoritas dalam bidangnya. Tidak tepat kata al-Shatiibi, memahami kata khatil dalam Q.S. al-Nisā':125 “Allah menjadikan Ibrahim khatil" sebagai seorang fakir karena pengertian itu bertentangan dengan naș al-Qur'ān yang lain, yaitu bahwa ia menjamu tamunya dengan daging anak sapi yang dipanggang (Q.S. Hud: 69) yang menunjukkan Ibrahim bukan seorang fakir, di samping bahwa kenyataan sejarah membuktikan bahwa Ibrahim bukan seorang fakir. Kedua, artiyang dipilih itu telah dikenal oleh bahasa Arab klasik. Dalam syarat ini terbaca bahwa "popularitas" artinya kosakata tak disinggung lagi, bahkan lebih jauh al-Shatibi menegaskan bahwa satu kosakata yang bersifat ambigius (mempunyai lebih dari satu makna), maka kesemua maknanya dapat digunakan bagi pengertian teks tersebut selama tak bertentangan satu dengan lainnya. Contoh kata "hidup" dan "mati". Al-Qur'ān menggunakan kata "mati" dalam arti berpisahnya ruh dari badan, dan juga dalam arti kosongnya jiwa dari nilai-nilai agama. Firman Allah dalam Q.S. al-Rum: 19 "Dia Allah yang mengeluarkan yang mati dari yang hidup” dapat diartikan dengan salah satu atau dengan kedua arti tersebut di atas, demikian pula sebaliknya kata mati. ${ }^{10}$

'Ibid, hal. 37.

${ }^{10} \mathrm{M}$ Quraish Shihab, "Persoalan-Persoalan Penafsiran Metaforis Atas Fakta-Fakta Tekstual" dalam Budhy Munawar Rahman (ed), Kontekstualisasi Doktrin Islam Dalam Sejarah, (Jakarta: Yayasan Paramadina, 1994), hal. 5. 


\section{Konteks dan Latar Belakang Turunnya Al-Qur'ān}

Bagian dari tugas untuk memahami pesan al-Qur'ān sebagai suatu kesatuan adalah mempelajarinya dengan sebuah latar belakang. Latar belakang langsungnya adalah aktivitas $\mathrm{Nabi}$ dan perjuangannya selama kurang lebih 23 tahun di bawah bimbingan al-Qur'an. Karena perjuangan Nabi sendirilah yang sesungguhnya berhak memperoleh sebutan Sunnah, maka adalah penting untuk memahami sebaik mungkin milieu Arab pada masa awal penyebaran Islam, sebab aktivitas Nabi mensyaratkan adanya milieu itu. Dengan demikian, adat-istiadat, pranata-pranata, dan pandangan hidup orang Arab pada umumnya menjadi sangat penting untuk memahami aktivitas Nabi. Situasi di Makkah khususnya sebelum Islam datang juga membutuhkan suatu pemahaman yang mendalam. Suatu usaha harus dilakukan tidak hanya untuk memahami agama Arab pra Islam, tetapi juga pranata-pranata sosial, kehidupan ekonomis, dan hubungan-hubungan politik mereka serta pengaruh kekuasaan religio-ekonomis suku Quraisy di kalangan orang-orang Arab. Al-Qur'an harus difahami dalam konteksnya yang tepat, yaitu dalam konteks dan latar belakang perjuangan Nabi. ${ }^{11}$

\section{Contoh Ayat Tentang Kepemimpinan Dalam Keluarga}

Salah satu ayat yang seringkali dikaitkan dengan masalah gender dan tafsirannya menjadi perdebatan antara ulama klasik dan modern (feminis) adalah surat al-Nisā', ayat 34 , sebagai berikut:

$$
\text { فالصلحت قالتت حال حفظت علي النساء.مافضل الله بعضهم علي بعض و.بماانفقوامن اموالهم }
$$

"Fazlur Rahman, Neomodernisme Islam, terj. A hsin Muhammad (Bandung;: Mizan, 1987), hal. 55-56. 
Secara lahiriyah ayat di atas, ada dua macam bentuk kalimat. Pertama berbentuk kenyataan atau kalam khabari sedangkan bagian kedua berbentuk perintah dan larangan atau katam insha $\vec{i}$. Sebagai sebuah pernyataan, kalimat pertama memberi informasi tentang kelebihan (yang berupa fungsi kepemimpinan) satu kelompok (laki-laki) atas kelompok yang lain (perempuan) dengan beberapa catatan. Catatan tersebut memberikan petunjuk tentang mengapa kelompok yang satu memiliki kelebihan atas yang lain. Pernyataan tersebut ditujukan kepada komunitas umat Islam dimana wahyu diturunkan waktu itu. Karena bentuknya pernyataan, maka ayat tersebut tidak secara tegas merupakan perintah atau larangan, sehingga lebih mengedepankan substansi kelebihannya dari pada kelompoknya. Sedangkan bagian kedua yang berbentuk perintah dan larangan memberikan petunjuk tentang kasus spesifik dari penerapan bentuk pernyataan tersebut dalam kaitan hubungan suami istri.

Al-Ṭabarì menyebutkan bahwa sebab turun atau nuqū ayat ini berkaitan dengan peristiwa yang dialami oleh Sa'd ibn Rabi' dan istrinya, Habibah binti Zayd ibn Abi Zuhayr. Diriwayatkan bahwa suatu ketika Habibah nushüz terhadap suaminya, Sa'd. Karena perbuatan tersebut, Sa'd memukulnya. Mendapat perlakuan demikian Habibah mengadu kepada ayahnya. Kemudian ia bersama ayahnya mengadukan peristiwa ini kepada Rasulullah SAW. Rasulullah menganjurkan Habibah untuk membalasnya dengan yang setimpal (qișās).Setelah itu keduanya bermaksud kembali ke rumah. Namun ketika Habibah dan ayahnya baru sampai di luar rumah Rasulullah, maka turunlah ayat ini. Setelah itu Rasulullah memanggil keduanya lalu bersabda: "Kita menginginkan suatu cara, Allah menginginkan cara yang lain. Dan yang diinginkan Allah itulah yang terbaik".

$$
\text { أردنا أمرا وأرادالله أمرا والذي أرادالله خير }
$$

Kemudian dibatalkanlah hukum qișaș, sebagai balasan pemukulan oleh suami terhadap istrinya. Sedang bagi seorang istri Allah memberikan dua sifat yaitu qänitat dan băfizăat. ${ }^{12}$

${ }^{12} \mathrm{Ibn}$ Ja'far Muhammad ibn Jarì al-Tabari, Jami' al-Bayān 'an Ta'vil al-Qur'ān (Mesir: Musțafa al-Babi al-Halabi wa Auladuh, 1968), V: 110; Abū 'Abd Allāh Muhammad ibn Ahmad 
Sementara itu al-Qurțubi telah menghubungkan sebab turunnya ayat 34 dari surat al-Nisâ-' ini dengan sebab turunnya ayat diwajibkannya berjihad dan masalah waris serta terjadinya pemukulan seorang suami terhadap istrinya. Menurut suatu riwayat, Ummu Salamah telah bertanya kepada Rasulullah tentang kewajiban berjihad pada laki-laki sedangkan wanita tidak. Demikian pula halnya ia menanyakan bagian waris wanita yang lebih kecil dibandingkan dengan laki-laki maka turunlah ayat ini. ${ }^{13}$

Hampir sama dengan al-Tabarî, al-Rāzi juga menghubungkan sebab turunnya ayat ini dengan masalah waris. Menurut al-Räzi, Allah telah memberikan keistimewaan dalam masalah hak waris terhadap laki-laki karena laki-laki itu merupakan pemimpin bagi kaum wanita. Di samping itu, apabila terjadi istimta', maka Allah mewajibkan kepada kaum laki-laki.

Ayat tersebut di atas tidak terlepas dari ayat sebelumnya, yaitu surat al-Nisâ' ayat 32 dan 33, yang selengkapnya :

$$
\begin{aligned}
& \text { ولاتتمنوا مافضل الله به بعضكم علي بعض للرجال نصيب مما كتسبوا }
\end{aligned}
$$

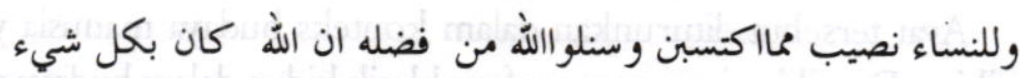

$$
\begin{aligned}
& \text { عليما ولكل جعلنا مولي مماترك الوالدان والاقربون والذين عقدت ايمنكم } \\
& \text { فاتوهم نصيبهم ان الله كان علي كل شئ شهيدا }
\end{aligned}
$$

Ayat tersebut di atas berkenaan dengan pembagian waris dimana setiap individu (berdasarkan jenis kelamin) memiliki bagian yang telah ditentukan. Ketentuan tersebut membedakan perolehan antar satu individu dari yang lainnya karena dikaitkan dengan fungsinya. Karena perbedaan tersebut dikarenakan adanya fungsi yang berbeda, maka Allah melarang iri atas adanya perbedaan tersebut.

al-Anșārì al-Qurțubi, Al-Jamì' li Aḅkām al-Qur'än (Beirut: Dār al-Kutub al-Tlmiyyah, tt), hal 57.

${ }^{13} \mathrm{Al}-\mathrm{Qurtwubi}$, Al-Jami', hal. 111. 
Sebagai kelanjutan dari ayat tersebut, ayat 34 memperjelas tentang mengapa setiap individu dalam keluarga tidak boleh iri satu sama lain atas bagiannya. Dalam keluarga, kedudukan masing-masing individu berbeda dikarenakan adanya perbedaan fungsi dan tanggung jawab dalam mendukung berjalannya keluarga. Karena itulah setiap kedudukan tersebut harus dikaitkan dengan fungsi dan tanggung jawab, tidak secara mutlak dikaitkan dengan jenis kelamin. Kedudukan yang didasarkan jenis kelamin semata dapat menimbulkan iri di antara anggota keluarga. Akan tetapi, bila kedudukan tersebut dikaitkan dengan fungsi dan tanggung jawab tidak selayaknya menimbulkan iri.

Dalam sejarah, budaya manusia didominasi oleh sistem patriakhal, dimana laki-laki mendominasi sistem kehidupan keluarga maupun publik. Dalam budaya yang demikian peran perempuan menjadi marginal dan hanya pelengkap bagi laki-laki. Budaya ini muncul karena kekuatan individu secara fisik untuk bertahan hidup pada masa lalu sangat penting. Karena secara alamiah laki-laki memiliki fisik yang lebih dibandingkan perempuan, maka mereka memiliki kedudukan yang lebih dibandingkan perempuan. ${ }^{14}$

Ayat tersebut diturunkan dalam konteks budaya manusia yang demikian. Demikian juga, para mufasir klasik hidup dalam budaya yang patriakhal. Karena itu, pemahaman mereka akan ayat tersebut lebih bersifat harfiah karena sesuai dengan budaya dan praktik keseharian masyarakat pada waktu itu. Keadaan alam Arab dimana ayat tersebut diturunkan sangat keras sehingga kekuatan fisik menjadi andalan untuk bisa bertahan hidup. Dalam keadaan yang seperti ini, budaya patriakhal dapat berkembang secara subur. Dalam budaya ini, laki-laki memiliki nilai yang lebih dibandingkan perempuan sehingga pantaslah mereka menjadi pemimpin atas perempuan karena kelebihannya tersebut.

Namun demikian, perubahan budaya manusia yang tidak lagi mengandalkan kekuatan fisik menuntut pemahaman ulang atas ayat

${ }^{14}$ Nasarudin Umar, Argumentasi Kesetaraan Jender: Perspektif Al-Qur'än (Jakarta: Paramadina, 1999), hal. 55. 
tersebut, tanpa meninggalkan makna hakiki yang dikandung oleh ayat tersebut. Pada dasarnya ayat tersebut menekankan perlunya "kelebihan" yang harus dimiliki seorang pemimpin atas yang dipimpinnya. Kelebihan tersebut menjadi syarat yang harus dimiliki agar kepemimpinan berhadil dengan baik.

Karena pada saat ini kelebihan individu tidak lagi ditentukan oleh kekuatan fisik, maka kepemimpinanpun tidak lagi relevan bila hanya didasarkan pada jenis kelamin semata. Kelebihan tersebut sangat dimungkinkan dimiliki oleh siapa saja, baik laki-laki maupun perempuan. Karena itu prinsip dasar seorang pemimpin adalah karena kepemilikan "kelebihan" atas yang lain, maka siapa-pun yang memiliki kelebihan tersebut dapat menjadi pemimpin tanpa harus dikaitkan dengan jenis kelamin. Dengan demikian, ayat tersebut tetap relevan dengan perkembangan budaya manusia pada saat ini.

\section{E. Penutup}

1. Tafsir adalah penjelasan tentang arti dan maksud firman-firman Allah SWT yang tercantum dalam al-Qur'ān sesuai dengan kemampuan manusia yang telah memiliki seperangkat syarat-syarat tertentu.

2. Al-Qur'an yang bersifat șälị li-kulli zamān rea makān (sesuai dengan segala waktu dan tempat) selalu mengundang problem interpretasi: ada yang memahami dan menafsirkan secara literal ada pula yang memahami secara kontekstual, memahami sesuai dengan pesan dan elanvital atau spirit al-Qur'an.

3. Alternatif penafsiran modern Al-Qur’ann harus dilakukan dengan pendekatan multi disipliner (menggunakan analisis semantik, historis, dan perkembangan sosio-kultural). 
Syufa'at

\section{DAFTAR PUSTAKA}

Shihab, M. Quraish. Membumikan Al-Qur'än. Bandung: Mizan, 1992. 1991.

"Tafsir dan Modernisasi" dalam Ulumul Qur'ān, No. 8, vol. II,

'Kata Pengantar' pada Shaikh Muhamad al-Ghazāli, Studi Kritis Atas Hadis. Bandung: Mizan,1994.

"Persoalan-Persoalan Penafsiran Metaforis Atas Fakta-Fakta Tekstual" dalam Budhy Munawar Rahman (ed), Kontekstualisasi Doktrin Islam Dalam Sejarah. Jakarta: Yayasan Paramadina, 1994.

Al-Dzahabi, Muhammad Husayn. Al-Tafsir wa al-Mufassirūn, 2 jilid. Mesir: Dār al-Kutub al-Hadithah, 1961.

Rahman, Fazlur. Neomodernisme Islam, terj. Ahsin Muhammad. Bandung: Mizan, 1987.

Yayasan Penterjemah Al-Qur'an. Al-Qur'än dan Terjemahannya. Jakarta: Proyek Pengadaan Kitab Suci al-Qur'an, 1983.

Al-T?abarî, ibn Ja'far Muhammad ibn Jarîr. Jamî' al-Bayân 'an Ta'wîl al-Qur'ān, 8 jilid. Mesir: Musțafâ al-Babi al-Halabi wa Auladuh, 1968.

Al-Qurțubi, Abū 'Abd Allāh Muhammad ibn Ahmad al-Anșāri, Al-Jamì' li Aḅkäm al-Qur'ān. Beirut: Dār al-Kutub al-'Ilmiyyah, t.t.

Umar, Nasarudin. Argumentasi Kesetaraan Jender: Perspektif Al-Qur'an. Jakarta: Paramadina, 1999. 